\title{
Pemilhan Pemasok Bahan Baku Kayu Handle Raket Dengan Menggunakan Metode Fuzzy Analitycal Hierarchy Process
}

\author{
Yofa Pangestu \\ Jurusan Teknik Industri, Fakultas Teknik, Universitas Muhammadiyah Malang \\ Jl. Raya Tlogomas 246 Malang, Jawatimur, Indonesia \\ *Surel: yofa.pangestu1@gmail.com
}

\begin{abstract}
Eternal racket company located in the Klayatan is a company engaged in manufacturing, where output is produced in the form of sports equipment. Given these problems, the Company is required Eternal racket must evaluate suppliers and choose which supplier should be selected with a view limits the capacity and various characteristics of suppliers. For that decision-making in the selection of suppliers is very important. Based on this problem researchers try to provide alternative solutions to the problem of decision-making by integrating the F-AHP is the combination of AHP technique to approach the concept of fuzzy logic. Although AHP is used in dealing with qualitative and quantitative criteria in MCDM but fuzzy AHP is considered better in describing vague decision of the AHP. and the supplier is a supplier selected priority $A$ ( $P \_A$ ) with highest weight is 0.389 .
\end{abstract}

Keywords: AHP, Fuzzy, Fuzzy AHP

\begin{abstract}
Abstrak
Perusahaan Raket Abadi adalah perusahaan yang memproduksi peralatan olahraga. Permasalahan perusahaan Raket Abadi adalah adanya sejumlah pemasok yang memasok item handle raket dengan berbagai kualitas. Dengan adanya permasalahan tersebut, Perusahaan Raket Abadi dituntut harus melakukan evaluasi pemasok dan memilih pemasok mana yang sebaiknya dipilih dengan melihat batasan kapasitas dan berbagai karakteristik dari pemasok. Untuk itu, pengambilan keputusan dalam pemilihan pemasok yang tepat sangat penting. Berdasarkan permasalahan ini peneliti mencoba memberikan alternatif pemecahan masalah pengambilan keputusan dengan mengintegrasikan F-AHP merupakan penggabungan dari teknik AHP dengan pendekatan konsep logika fuzzy. Walaupun AHP biasa digunakan dalam menangani kriteria kualitatif dan kuantitatif pada MCDM namun fuzzy AHP dianggap lebih baik dalam mendeskripsikan keputusan yang samar-samar dari pada AHP. dan pemasok prioritas yang terpilih adalah pemasok $A\left(P \_A\right)$ dengan bobot tertinggi yaitu 0,389.
\end{abstract}

Kata kunci: AHP, Fuzzy, Fuzzy AHP

\section{Pendahuluan}

Dengan semakin berkembangnya dunia industri pada saat ini akan berakibat pada persaingan yang akan di hadapi juga semakin tinggi. Perusahaan-perusahaan berupaya untuk meningkatkan kinerjanya dalam rangka menghasilkan suatu output yang optimal, yang mampu memenuhi keinginan konsumen. Salah satu faktor yang mempengaruhi kinerja perusahaan adalah keberadaan pemasok yang berperan sebagai pemasok bahan baku. Keberadaan pemasok ini sangat menentukan kelancaran proses produksi yang dihasilkan.

Setiap perusahaan, umumnya memiliki lebih dari satu pemasok untuk memasok material yang dibutuhkan. Hal ini berfungsi untuk meningkatkan kekuatan tawarmenawar yang dimiliki perusahaan dan juga untuk menjaga ketersediaan produk. 
Berbagai masalah yang berhubungan dengan pemasok sering muncul. Misalnya, kualitas tidak sesuai spesifikasi dan keterlambatan pengiriman. Untuk itu perusahaan harus melakukan evaluasi dan pemilihan terhadap pemasok, evaluasi dan pemilihan pemasok dilakukan sesuai dengan karakteristik masing-masing produk atau barang yang akan dipasok.

Perusahaan Raket Abadi yang berlokasi di jalan Klayatan adalah perusahaan yang bergerak di bidang manufaktur, dimana output yang di hasilkan berupa peralatan olahraga. Saat ini Perusahaan Raket Abadi sedang menghadapi permasalahan dengan sejumlah pemasok yang memasok item handle raket berupa kayu. Sebagai contoh dari sudut kualitas beberapa dari pemasok memiliki kualitas kayu yang kurang terlalu baik namun harga lebih murah di bandingkan pemasok lain, kemudian beberapa pemasok lainnya memiliki kualitas produk yang bagus namun pemasok tersebut melebihi lead time dalam pengiriman produk yang telah di sepakati sehingga keterlambatan memasok material yang nantinya akan menghambat proses produksi. Banyak kriteria lainnya dari pemasok yang memiliki kekurangan dan kelebihan masing-masing dalam memasok material. Dengan adanya permasalahan tersebut, Perusahaan Raket Abadi dituntut harus melakukan evaluasi pemasok dan memilih pemasok mana yang sebaiknya dipilih dengan melihat batasan kapasitas dan berbagai karakteristik dari pemasok.

Metode yang sering dipakai dalam proses pengambilan keputusan yaitu metode Analytic Hierarchy Process yang biasa disebut AHP[1]. Metode AHP adalah prosedur yang berbasis matematis untuk mengevaluasi kriteria-kriteria tersebut. AHP juga memperhitungkan validitas data dengan adanya batas toleransi inkonsistensi berbagai kriteria yang dipilih[2]. Walaupun metode AHP telah banyak digunakan untuk membantu dalam pengambilan keputusan, tetapi metode AHP tak luput dari kritikan dalam penggunaannya karena dianggap tidak seimbang dalam skala penilaian perbandingan berpasangan [3].

Skala AHP yang berbentuk bilangan "crisp" (tegas) dianggap kurang mampu menangani ketidakpastian[4]. Oleh karena itu, skala AHP orisinal harus dekati dengan metode yang lain. Salah satu pendekatan yang patut dipertimbangkan adalah dengan menggunakan pendekatan logika fuzzy [5]. Logika Fuzzy merupakan sebuah logika yang memiliki nilai kekaburan atau kesamaran (Fuzzyness) antara dua nilai[6]. Pendekatan fuzzy khususnya pendekatan triangular fuzzy number terhadap skala AHP diharapkan mampu untuk meminimalisasi ketidakpastian sehingga diharapkan hasil yang diperoleh lebih akurat ([7].

Berdasarkan permasalahan ini peneliti mencoba memberikan alternatif pemecahan masalah pengambilan keputusan dengan mengintegrasikan F-AHP merupakan penggabungan dari teknik AHP dengan pendekatan konsep logika fuzzy. Walaupun AHP biasa digunakan dalam menangani kriteria kualitatif dan kuantitatif pada MCDM namun fuzzy AHP dianggap lebih baik dalam mendeskripsikan keputusan yang samar-samar dari pada AHP.

\section{Metode Penelitian}

Dalam proeses pemilihan pemasok untuk bahan baku kayu handle raket di Perusahan Raket "ABADI" Malang menggunakan metode Fuzzy AHP yang merupakan gabungan dari metode Fuzzy dan AHP. Menurut Raharjo dkk F-AHP adalah gabungan dari metode AHP dengan pendekatan konsep fuzzy. Nilai numerik yang di gunakan untuk perbandingan AHP berdasarkan skala perbandingan [8], dapat dilihat pada table 1 . 
Tabel 1. Skala Banding Berpasangan.

\begin{tabular}{|c|c|c|}
\hline Intensitas kepentingan & Keterangan & Penjelasan \\
\hline 1 & $\begin{array}{l}\text { Kedua elemen sama } \\
\text { pentingnya }\end{array}$ & $\begin{array}{l}\text { Dua elemen menyumbangnya } \\
\text { sama besar pada sifat itu }\end{array}$ \\
\hline 3 & $\begin{array}{l}\text { Elemen yang satu sedikit } \\
\text { lebih penting dari yang } \\
\text { lainnya }\end{array}$ & $\begin{array}{l}\text { Pengalaman dan } \\
\text { pertimbangan } \\
\text { menyokong satu elemen atas } \\
\text { yang lainnya }\end{array}$ \\
\hline 5 & $\begin{array}{l}\text { Elemen yang satu "Essensial" } \\
\text { atau sangat penting dari } \\
\text { elemen yang lainnya. }\end{array}$ & $\begin{array}{l}\text { Pengalaman dan } \\
\text { pertimbangan dengan kuat } \\
\text { menyokong satu elemen atas } \\
\text { yang lainnya }\end{array}$ \\
\hline 7 & $\begin{array}{l}\text { Satu elemen "jelas lebih } \\
\text { penting" dari elemen yang } \\
\text { lainnya }\end{array}$ & $\begin{array}{l}\text { Satu elemen dengan kuat } \\
\text { disokong dan dominannya } \\
\text { telah terlihat dalam praktek }\end{array}$ \\
\hline 9 & $\begin{array}{l}\text { Satu elemen "mutlak lebih } \\
\text { penting" dari elemen yang } \\
\text { lainnya }\end{array}$ & $\begin{array}{l}\text { Bukti yang menyokong } \\
\text { elemen yang satu atas yang } \\
\text { lain memiliki tingkat } \\
\text { penegasan tertinggi yang } \\
\text { mungkin menguatkan }\end{array}$ \\
\hline $2,4,6,8$ & $\begin{array}{l}\text { Nilai-nilai diantara dua } \\
\text { pertimbangan } \\
\text { berdekatan }\end{array}$ & $\begin{array}{lr}\text { Nilai ini } & \text { diberikan bila } \\
\text { diperlukan } & \text { kompromi } \\
\text { diantara dua } & \text { pertimbangan }\end{array}$ \\
\hline Kebalikan & \multicolumn{2}{|c|}{$\begin{array}{l}\text { Jika suatu aktivitas I mendapat satu angka bila dibandingkan } \\
\text { dengan aktivitas j, maka j mempunyai nilai kebalikannya bila } \\
\text { dibandingkan dengan I }\end{array}$} \\
\hline
\end{tabular}

Tahap awal dalam perhitungan AHP [9] adalah membandingkan nilai dari masingmasing kriteria dan subkriteria yang di berikan dari Decision Maker. Secara umum langkah-langkah yang harus dilakukan dalam menggunakan AHP untuk pemecahan suatu masalah adalah sebagai berikut [8] : (1) Mendefenisikan masalah dan menentukan solusi yang diinginkan. (2) Membuat struktur hirarki yang diawali dengan tujuan umum, dilanjutkan dengan kriteria-kriteria dan alternatif - alternatif pilihan yang ingin di rangking. (3) Membentuk matriks perbandingan berpasangan yang menggambarkan kontribusi relatif atau pengaruh setiap elemen terhadap masing-masing tujuan atau kriteria yang setingkat diatas. Perbandingan dilakukan berdasarkan pilihan atau judgement dari pembuat keputusan dengan menilai tingkat-tingkat kepentingan suatu elemen dibandingkan elemen lainnya. (4) Menormalkan data yaitu dengan membagi nilai dari setiap elemen di dalam matriks yang berpasangan dengan nilai total dari setiap kolom. (5) Menghitung eigen vector dari setiap matriks perbandingan berpasangan. Nilai eigen vector merupakan bobot setiap elemen. Langkah ini untuk mensintetis pilihan dalam penentuan prioritas elemen pada tingkat hirarki terendah sampai pencapaian tujuan. (6) Menguji konsistensi hirarki.

Langkah-Langkah pengujian konsistensi data adalah sebagai berikut menurut, Saaty [8]:Menghitung indeks konsistensi dengan rumus sebagai berikut

Indeks Konsistensi $(\mathrm{CI})=\frac{\lambda_{\text {maks }}-n}{n-1}$

Menghitung rasio konsistensi, dengan rumus sebagai berikut:

Ratio konsistensi $(\mathrm{CR})=\frac{C I}{R I}$ 
Tabel 2. (Random Index)

\begin{tabular}{cc}
\hline $\mathrm{N}$ & $\mathrm{RI}$ \\
\hline 1 & 0,00 \\
2 & 0,00 \\
3 & 0,58 \\
4 & 0,90 \\
5 & 1,12 \\
6 & 1,24 \\
7 & 1,31 \\
8 & 1,41 \\
9 & 1,45 \\
10 & 1,49 \\
\hline
\end{tabular}

Sumber : Saaty [8]

Penilaian dikatakan konsistensi apabila ratio konsistensi $\leq 0.1$ maka ada unsur acak didalam memberikan penilaian. F-AHP menutupi kelemahan yang terdapat pada AHP, yaitu permasalahan terhadap kriteria yang memiliki sifat subjektif lebih banyak. Ketidakpastian bilangan dipresentasikan dengan urutan skala. Untuk menentukan derajat keanggotaan pada F-AHP, digunakan aturan fungsi dalam bentuk bilangan fuzzy segitiga atau Triangular Fuzzy Number (TFN). Skala fuzzy segitiga yang dapat pada tabel 3 [10]:

Tabel 3. Skala nilai fuzzy segitiga menurut Deng [10]

\begin{tabular}{|c|c|c|c|}
\hline $\begin{array}{c}\text { Intensitas } \\
\text { Kepentingan AHP }\end{array}$ & Himpunan Linguistik & $\begin{array}{l}\text { Triangular } \\
\text { Fuzzy Number } \\
\text { (TFN) }\end{array}$ & $\begin{array}{l}\text { Reciprocal } \\
\text { (Kebalikan) }\end{array}$ \\
\hline 1 & $\begin{array}{l}\text { Perbandingan elemen yang } \\
\text { sama (just equaly) }\end{array}$ & $1,1,3$ & $1 / 3,1 / 1,1 / 1$ \\
\hline 2 & $\begin{array}{l}\text { Pertengahan(Intermediate) } \\
\text { Elemen satu cukup penting }\end{array}$ & $1,2,4$ & $1 / 4,1 / 2,1 / 1$ \\
\hline 3 & $\begin{array}{c}\text { dari yang lainnya } \\
\text { (moderately important) }\end{array}$ & $1,3,5$ & $1 / 5,1 / 3,1 / 1$ \\
\hline 4 & $\begin{array}{c}\text { Pertengahan } \\
\text { (Intermediate) elemen } \\
\text { yang satu lebih cukup } \\
\text { penting dari yang lainnya. } \\
\text { Elemen satu kuat }\end{array}$ & $2,4,6$ & $1 / 6,1 / 4,1 / 2$ \\
\hline 5 & $\begin{array}{l}\text { pentingnya dari yang lain } \\
\text { (Strongly Important) }\end{array}$ & $3,5,7$ & $1 / 7,1 / 5,1 / 3$ \\
\hline 6 & $\begin{array}{l}\text { Pertengahan } \\
\text { (Intermediate) }\end{array}$ & $4,6,8$ & $1 / 8,1 / 6,1 / 4$ \\
\hline 7 & $\begin{array}{l}\text { Elemen satu lebih kuat } \\
\text { pentingnya dari yang } \\
\text { lainnya (Very Strong) }\end{array}$ & $5,7,9$ & $1 / 9,1 / 7,1 / 5$ \\
\hline 8 & $\begin{array}{l}\text { Pertengahan } \\
\text { (Intermediate) }\end{array}$ & $6,8,10$ & $1 / 10,1 / 8,1 / 6$ \\
\hline 9 & $\begin{array}{c}\text { Elemen satu mutlak lebih } \\
\text { penting dari yang lainnya } \\
\text { (Exremely Strong) }\end{array}$ & $7,9,11$ & $1 / 11,1 / 9,1 / 7$ \\
\hline
\end{tabular}

Metode extent analysis untuk nilai sintesis pada perbandingan berpasangan pada fuzzy AHP[3]. Adapun langkah-langkah penyelesaian F-AHP adalah: 
Menentukan nilai sintesis fuzzy ( $\mathrm{Si})$ prioritas dengan rumus:

$\mathrm{Si}=\sum_{j=1}^{m} M_{g i}^{j} x\left[\sum_{i=j}^{n} \sum_{j=1}^{m} M_{g i}^{j}\right]^{-1}$

Dimana:

Si = nilai sintesis fuzzy

$\sum_{j=1}^{m} M_{g i}^{j}=$ menjumlahkan nilai sel pada kolom yang dimulai dari kolom 1 di setiap baris matriks

$$
\begin{array}{ll}
\mathrm{J} & =\text { kolom } \\
\mathrm{I} & =\text { baris } \\
\mathrm{M} & =\text { bilangan triangular fuzzy number } \\
\mathrm{m} & =\text { jumlah kriteria } \\
\mathrm{g} & =\text { parameter }(\mathrm{l}, \mathrm{m}, \mathrm{u})
\end{array}
$$

untuk memperoleh $\sum_{j=1}^{m} M_{g i}^{j}$, dilakukan operasi penjumlahan untuk keseluruhan bilangan triangular fuzzy dalam matriks keputusan (n x m), sebagai berikut:

\section{Dimana:}

$$
\sum_{j=1}^{m} M_{g i}^{j}=\left(\sum_{j=1}^{m} l_{j}, \sum_{j=1}^{m} m_{j,} \sum_{j=1}^{m} u_{j}\right.
$$

$\sum_{j=1}^{m} l_{j,}=$ jumlah sel pada kolom pertama matriks (nilai lower)

$\sum_{j=1}^{m} m_{j,}=$ jumlah sel pada kolom kedua matriks (nilai median)

$\sum_{j=1}^{m} u_{j,}=$ jumlah sel pada kolom ketiga matriks (nilai upper)

Sehingga untuk menghitung invers persamaan, yaitu:

$$
\left[\sum_{j=1}^{m} \sum_{j=1}^{m} M_{g i}^{j}\right]^{-1}=\left(\frac{1}{\sum_{i=1}^{n} u i}, \frac{1}{\sum_{i=1}^{n} m i}, \frac{1}{\sum_{i=1}^{n} l i},\right)
$$

Perbandingan tingkat kemungkinan antara bilangan fuzzy. Digunakan untuk nilai bobot pada masing-masing kriteria. Untuk dua bilangan triangular fuzzy $\mathrm{M} 1=(11$, $\mathrm{m} 1$, u1) dan $\mathrm{M} 2=(12, \mathrm{~m} 2$, u2) dengan tingkat kemungkinan (M2 $\geq \mathrm{M} 1)$ dapat didefinisikan sebagai berikut:

$$
\mathrm{V}(\mathrm{M} 2 \geq M 1)=\sup \left[\min \left(\mu_{m_{1}}(\mathrm{x}), \mu_{m_{2}},(\mathrm{y})\right)\right]
$$

Tingkat kemungkinan untuk bilangan fuzzy konveks dapat diperoleh dengan persamaan berikut:

$$
\mathrm{V}(\mathrm{M} 2 \geq M 1)=\left\{\begin{array}{cc}
1 ; & \text { jika } m_{2} \geq m_{1} \\
0 ; & \text { jika } l_{1} \geq u_{2} \\
\frac{l_{1}-u_{2}}{\left(m_{2}-u_{2}\right)-\left(m_{1-l}\right)} ; & \text { jika kondisi lain }
\end{array}\right.
$$

Jika hasil nilai fuzzy lebih besar dari nilai $\mathrm{k}$ fuzzy, $\mathrm{Mi}=(\mathrm{i}=1,2,3, \ldots, \mathrm{k})$ yang dapat ditentukan dengan menggunakan operasi max dan min sebagai berikut:

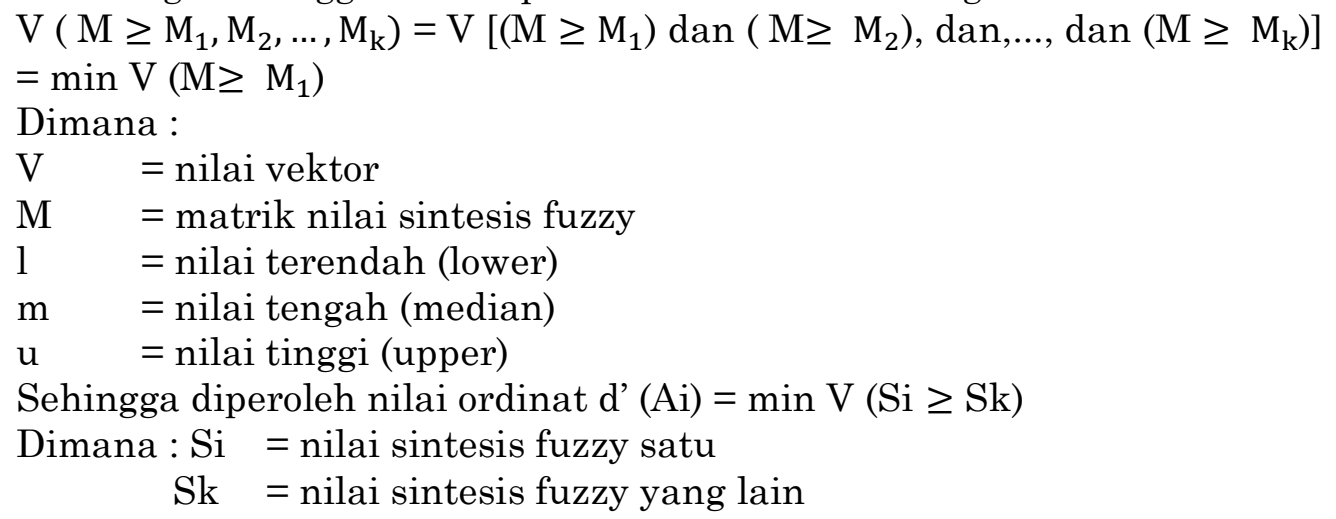


Untuk $\mathrm{k}=1,2, \ldots, \mathrm{n} ; \mathrm{k} \neq \mathrm{i}$ maka nilai vektor bobot di definisikan

$\mathrm{W}^{\prime}=\left(\mathrm{d}^{\prime}(\mathrm{A} 1), \mathrm{d}^{\prime}(\mathrm{A} 2), \ldots, \mathrm{d}^{\prime}(\mathrm{An})\right)^{\prime} \mathrm{T}$

Normalisasi nilai vektor atau nilai prioritas kriteria yang telah diperoleh, $W^{\prime}=\left(d^{\prime}\right.$ (A1), d' (A2), ..., d'(An))T

Perumusan normalisasinya adalah:

$\mathrm{d}\left(A_{n}\right)=\frac{d^{1}\left(A_{n}\right)}{\sum_{i=1}^{n} d^{1}\left(A_{n}\right)}$

Normalisasi bobot ini akan dilakukan agar nilai dalam vektor diperbolehkan menjadi analog bobot dan terdiri dari bilangan yang non-fuzzy.

\section{Hasil dan Pembahasan}

Pemilihan pemasok terbaik dilihat dari beberapa kriteria, diantaranya adalah 6 kriteria yaitu : Kualitas (K), Harga (H), Service(S), Pengiriman (P), Fleksibel (F), dan Sistem komunikasi (SK). Untuk menghitung dan menetapan konsistensi untuk perbandingan berpasangan antar kriteria utamanya dapat dilihat pada tabel 4 : Langkah 1 Membentuk matriks perbandingan berpasangan.

Tabel 4. Matrik perbandingan kriteria Utama

\begin{tabular}{lllllll}
\hline Kriteria & $\mathrm{K}$ & $\mathrm{H}$ & $\mathrm{S}$ & $\mathrm{P}$ & $\mathrm{F}$ & $\mathrm{Sk}$ \\
\hline $\mathrm{K}$ & 1 & 1 & 2 & 2 & 3 & 6 \\
$\mathrm{H}$ & 1 & 1 & 5 & 3 & 3 & 4 \\
$\mathrm{~S}$ & $1 / 2$ & $1 / 5$ & 1 & 2 & 3 & 4 \\
$\mathrm{P}$ & $1 / 2$ & $1 / 3$ & $1 / 2$ & 1 & 1 & 2 \\
$\mathrm{~F}$ & $1 / 3$ & $1 / 3$ & $1 / 3$ & 1 & 1 & 3 \\
Sk & $1 / 6$ & $1 / 4$ & $1 / 4$ & $1 / 2$ & $1 / 3$ & 1 \\
Jumlah & $7 / 2$ & $187 / 60$ & $109 / 12$ & $19 / 2$ & $34 / 3$ & 20 \\
\hline
\end{tabular}

Langkah 2. Normalisasi data yaitu dengan membagi nilai dari setiap elemen didalam matriks yang berpasangan dengan nilai total dari setiap kolom.

Tabel 5. Pembagian Matrik Perbandingan Kriteria

\begin{tabular}{lllllll}
\hline Kriteria & $\mathrm{K}$ & $\mathrm{H}$ & $\mathrm{S}$ & $\mathrm{P}$ & $\mathrm{F}$ & $\mathrm{Sk}$ \\
$\mathrm{K}$ & $1: 7 / 2$ & $1: 187 / 60$ & $2: 109 / 12$ & $2: 19 / 2$ & $3: 34 / 3$ & $6: 20$ \\
& $=2 / 7$ & $=60 / 187$ & $=24 / 109$ & $=4 / 19$ & $=9 / 34$ & $=3 / 10$ \\
$\mathrm{H}$ & $1: 7 / 2$ & $1: 187 / 60$ & $5: 109 / 12$ & $3: 19 / 2$ & $3: 34 / 3$ & $4: 20$ \\
& $=2 / 7$ & $=60 / 187$ & $=60 / 109$ & $=6 / 19$ & $=9 / 34$ & $=1 / 5$ \\
$\mathrm{~S}$ & $1 / 2: 7 / 2$ & $1 / 5: 187 / 60=$ & $1: 109 / 12$ & $3: 19 / 2$ & $3: 34 / 3$ & $4: 20$ \\
& $=1 / 7$ & $12 / 187$ & $=12 / 109$ & $=6 / 19$ & $=9 / 34$ & $=1 / 5$ \\
$\mathrm{P}$ & $1 / 2: 7 / 2$ & $1 / 3: 187 / 60=$ & $1 / 2: 109 / 12$ & $1: 19 / 2$ & $1: 34 / 3$ & $2: 20$ \\
& $=1 / 7$ & $20 / 187$ & $=6 / 109$ & $=2 / 19$ & $=3 / 34$ & $=1 / 20$ \\
$\mathrm{~F}$ & $1 / 3: 7 / 2$ & $1 / 3: 187 / 60=$ & $1 / 3: 109 / 12$ & $1: 19 / 2$ & $1: 34 / 3$ & $3: 20$ \\
& $=2 / 21$ & $20 / 187$ & $4 / 109$ & $=2 / 19$ & $=3 / 34$ & $=3 / 20$ \\
$\mathrm{Sk}$ & $1 / 6: 7 / 2$ & $1 / 4: 187 / 60=$ & $1 / 4: 109 / 12$ & $1 / 2: 19 / 2$ & $1 / 3: 34 / 3$ & $1: 20$ \\
& $=1 / 21$ & $15 / 187$ & $=3 / 109$ & $=1 / 19$ & $=1 / 34$ & $=1 / 20$ \\
\hline
\end{tabular}

Langkah 3. Setiap elemen didalam matriks di jadikan dalam bentuk desimal dan menghitung bobot prioritasnya. 
Tabel 6. Penentuan Bobot prioritas Kriteria

\begin{tabular}{ccccccccc}
\hline \multirow{2}{*}{ Kriteria } & $\mathrm{K}$ & $\mathrm{H}$ & $\mathrm{S}$ & $\mathrm{P}$ & $\mathrm{F}$ & $\mathrm{Sk}$ & & $\begin{array}{c}\text { Bobot } \\
\text { Prioritas }\end{array}$ \\
\hline $\mathrm{K}$ & 0,2857 & 0,3209 & 0,2202 & 0,2143 & 0,2647 & 0,3000 & $1,6058: 6$ & 0,2676 \\
$\mathrm{H}$ & 0,2857 & 0,3209 & 0,5505 & 0,3214 & 0,2647 & 0,2000 & $1,9433: 6$ & 0,3239 \\
$\mathrm{~S}$ & 0,1429 & 0,0642 & 0,1101 & 0,2143 & 0,2647 & 0,2000 & $0,9961: 6$ & 0,1660 \\
$\mathrm{P}$ & 0,1429 & 0,1069 & 0,0550 & 0,1071 & 0,0882 & 0,1000 & $0,6002: 6$ & 0,1000 \\
F & 0,0951 & 0,1069 & 0,0367 & 0,1071 & 0,0882 & 0,1500 & $0,5841: 6$ & 0,0973 \\
Sk & 0,0477 & 0,0802 & 0,0275 & 0,0357 & 0,0294 & 0,0500 & $0,2705: 6$ & 0,0451 \\
\hline \multicolumn{7}{c}{ Jumlah } \\
\hline
\end{tabular}

Langkah 4. Menghitung konsistensi

Menentukan nilai lamda max

$$
\begin{aligned}
& \lambda \max =(0,2627 \times 7 / 2)+(0,3239 \times 187 / 60)+(0,1660 \times 109 / 12)+(0,1000 \times 19 / 2)+(0,0973 \\
& \mathrm{x} \mathrm{34/3)}+(0,0451 \times 20)=6,3924
\end{aligned}
$$

Menghitung nilai CI dengan rumus sebagai berikut :

Indeks Konsistensi(CI) $=\frac{\frac{\lambda_{\text {maks }}-n}{n-1}}{n-1}=\frac{6,3924-6}{6-1}=0,3924$

Menghitung nilai CR dengan rumus sebagai berikut:

Ratio konsistensi $(\mathrm{CR})=\frac{C I}{R I}=\frac{0,3924}{1,24}$ konsisten.

Menurut Saaty, jika $C R \leq 10 \%$ maka matriks perbandingan berpasangan tersebut

\subsection{Pembobotan Dengan Fuzzy AHP}

\begin{tabular}{|c|c|c|c|c|c|c|c|c|c|c|c|c|c|c|c|c|c|c|}
\hline \multirow{2}{*}{ Kriteria } & \multicolumn{3}{|c|}{$\mathrm{K}$} & \multicolumn{3}{|c|}{$\mathrm{H}$} & \multicolumn{3}{|c|}{$\mathrm{S}$} & \multicolumn{3}{|c|}{$\mathrm{P}$} & \multicolumn{3}{|c|}{ F } & \multicolumn{3}{|c|}{ SK } \\
\hline & 1 & $\mathrm{M}$ & $\mathrm{u}$ & 1 & $\mathrm{~m}$ & $\mathrm{u}$ & 1 & $\mathrm{~m}$ & $\mathrm{u}$ & 1 & $\mathrm{~m}$ & $\mathrm{u}$ & 1 & $\mathrm{~m}$ & $\mathrm{u}$ & 1 & $\mathrm{~m}$ & U \\
\hline K & 1 & 1 & 3 & 1 & 1 & 3 & 1 & 2 & 4 & 1 & 2 & 4 & 1 & 3 & 5 & 4 & 6 & 8 \\
\hline $\mathrm{H}$ & 1 & 1 & 3 & 1 & 1 & 3 & 3 & 5 & 7 & 1 & 3 & 5 & 1 & 3 & 5 & 2 & 4 & 6 \\
\hline $\mathrm{S}$ & 0,25 & 0,5 & 1 & 0,14 & 0,2 & 0,3 & 1 & 1 & 3 & 1 & 2 & 4 & 1 & 3 & 5 & 2 & 4 & 6 \\
\hline $\mathrm{P}$ & 0,25 & 0,5 & 1 & 0,2 & 0,3 & 1 & 0,25 & 0,5 & 1 & 1 & 1 & 3 & 1 & 1 & 3 & 1 & 2 & 4 \\
\hline $\mathrm{F}$ & 0,2 & 0,33 & 1 & 0,2 & 0,3 & 1 & 0,2 & 0,3 & 1 & 0,33 & 1 & 1 & 1 & 1 & 3 & 1 & 3 & 5 \\
\hline SK & 0,13 & 0,17 & 0,3 & 0,17 & 0,3 & 0,5 & 0,17 & 0,3 & 1 & 0,25 & 0,5 & 1 & 0,2 & 0,33 & 1 & 1 & 1 & 3 \\
\hline
\end{tabular}

Tabel 7. Matriks perbandingan berpasangan Fuzzy

Berikut langkah-langkah perhitungan F-AHP :

Nilai Sintesis Fuzzy (Si)

Menghitung nilai sintesis fuzzy dengan operasi penjumlahan pada tiap-tiap bilangan triangular fuzzy number dalam setiap baris dan proses untuk mendapatkan nilai sintesis fuzzy. 
Tabel 8. Perhitungan penjumlahan baris dari kriteria F-AHP kriteria

\begin{tabular}{cccc}
\hline \multirow{3}{*}{ Kriteria } & \multicolumn{3}{c}{$\sum_{\boldsymbol{j}=\mathbf{1}}^{\boldsymbol{m}} \boldsymbol{M}_{\boldsymbol{g} \boldsymbol{i}}^{\mathbf{j}}$} \\
\cline { 2 - 4 } & $\mathrm{l}$ & $\mathrm{m}$ & $\mathrm{U}$ \\
\hline $\mathrm{K}$ & 9 & 15 & 27 \\
$\mathrm{H}$ & 9 & 17 & 29 \\
$\mathrm{~S}$ & 5,39 & 10,7 & 19,33 \\
$\mathrm{P}$ & 3,7 & 5,33 & 13 \\
$\mathrm{~F}$ & 2,93 & 5,99 & 12 \\
Sk & 1,91 & 2,50 & 6,25 \\
\hline Jumlah & 31,932 & 56,517 & 106,58 \\
\hline
\end{tabular}

Sehingga di peroleh nilai Si kriteria sebagai berikut :

Tabel 9. Nilai sintesis fuzzy kriteria

\begin{tabular}{lccc}
\hline \multirow{2}{*}{ Kriteria } & \multicolumn{3}{c}{$\mathrm{Si}$} \\
\cline { 2 - 4 } & $\mathrm{l}$ & $\mathrm{M}$ & $\mathrm{u}$ \\
\hline $\mathrm{K}$ & 0,084 & 0,265 & 0,846 \\
$\mathrm{H}$ & 0,084 & 0,301 & 0,908 \\
$\mathrm{~S}$ & 0,051 & 0,189 & 0,605 \\
$\mathrm{P}$ & 0,035 & 0,094 & 0,407 \\
$\mathrm{~F}$ & 0,027 & 0,106 & 0,376 \\
\hline Sk & 0,018 & 0,044 & 0,196 \\
\hline
\end{tabular}

Nilai Vektor Fuzzy (V) dan Nilai Ordinat defuzzifikasi $\left(d^{\prime}\right)$

Setelah melakukan perhitungan menggunakan sintesis fuzzy maka akan di peroleh nilai vektor F-AHP dengan rumus :

$$
\mathrm{V}(\mathrm{M} 2 \geq M 1)=\left\{\begin{array}{cc}
1 ; & \text { jika } m_{2} \geq m_{1} \\
0 ; & \text { jika } l_{1} \geq u_{2} \\
\frac{l_{1}-u_{2}}{\left(m_{2}-u_{2}\right)-\left(m_{1-l_{1}}\right)} ; & \text { jika kondisi lain }
\end{array}\right.
$$

Tabel 10. Nilai vektor fuzzy AHP kriteria

\begin{tabular}{ccccccc}
\hline Kriteria & $\mathrm{K} \geq$ & $\mathrm{H} \geq$ & $\mathrm{S} \geq$ & $\mathrm{P} \geq$ & $\mathrm{F} \geq$ & $\mathrm{Sk} \geq$ \\
\hline $\mathrm{K}$ & - & 1,00 & 0,873 & 0,654 & 0,647 & 0,336 \\
$\mathrm{H}$ & 0,955 & - & 0,823 & 0,609 & 0,600 & 0,304 \\
$\mathrm{~S}$ & 1,00 & 1,00 & - & 0,789 & 0,797 & 0,486 \\
$\mathrm{P}$ & 1,00 & 1,00 & 1,00 & - & 1,00 & 0,763 \\
$\mathrm{~F}$ & 1,00 & 1,00 & 1,00 & 0,969 & - & 0,732 \\
$\mathrm{Sk}$ & 1,00 & 1,00 & 1,00 & 1,00 & 1,00 & - \\
\hline
\end{tabular}


Menghitung nilai bobot vektor fuzzy (w')

Penentuan bobot vektor fuzzy dapat di hitung menggunkan persamaan rumus :

$\mathrm{W}^{\prime}=\left(\mathrm{d}^{\prime}\left(A_{1}\right), \mathrm{d}^{\prime}\left(A_{2}\right),,,, \mathrm{d}^{\prime}\left(A_{n}\right)\right)^{T}$ jumlahkan.

Dengan mengumpulkan semua koordinat (d') yang telah di peroleh selanjutnya di

Tabel 11. Nilai bobot vektor fuzzy AHP untuk kriteria

\begin{tabular}{lccccccc}
\hline & $\mathrm{d}^{\prime}(\mathrm{K})$ & $\mathrm{d}^{\prime}(\mathrm{H})$ & $\mathrm{d}^{\prime}(\mathrm{S})$ & $\mathrm{d}^{\prime}(\mathrm{P})$ & $\mathrm{d}^{\prime}(\mathrm{F})$ & $\mathrm{d}^{\prime}(\mathrm{Sk})$ & $\sum \mathrm{W}^{\prime}$ \\
\hline $\mathrm{W}^{\prime}$ & 0,955 & 1,00 & 0,823 & 0,609 & 0,600 & 0,304 & 4,291 \\
\hline
\end{tabular}

Normalisasi nilai bobot vektor fuzzy (w)

Pada tahap ini dilakukan normalisasi nilai bobot vektor fuzzy yaitu dengan membagi nilai bobot vektor dengan membagi nilai bobot itu sendiri dengan rumus sebagai berikut :

$\mathrm{d}\left(A_{n}\right)=\frac{d^{1}\left(A_{n}\right)}{\sum_{i=1}^{n} d^{1}\left(A_{n}\right)}$

Kemudian, nilai bobot vektor yang sudah di hasilkan dan dinormalisasi akan menghasilkan jumlah nilai bobot yang bernilai 1 .

Tabel 12. Normalisasi nilai bobot vektor fuzzy AHP untuk kriteria

\begin{tabular}{lllllllll}
\hline & $\mathrm{K}$ & $\mathrm{H}$ & $\mathrm{S}$ & $\mathrm{P}$ & $\mathrm{F}$ & $\mathrm{Sk}$ & $\sum \mathrm{W}$ \\
\hline $\mathrm{W}$ & 0,223 & 0,233 & 0,192 & 0,142 & 0,140 & 0,071 & 1 \\
\hline
\end{tabular}

Untuk perhitungan subkriteria dan alternatif pemasok sama langakah pengerjaan sama dengan cara ini.

\subsection{Perangkingan Alternatif dan Hasil Keputusan}

Perangkingan alternatif dan hasil keputusan merupakan tahap terakhir untuk menentukan hasil keputusan, Berikut ini adalah tabel bobot prioritas alternatif (BPA) dan bobot global alternatif :

Tabel 13. Bobot prioritas subkriteria "Kualitas"

\begin{tabular}{ccccccc}
\hline $\begin{array}{c}\text { Subkriteria } \\
\text { kualitas }\end{array}$ & $\mathrm{K} 1$ & $\mathrm{~K} 2$ & $\mathrm{~K} 3$ & $\mathrm{~K} 4$ & $\mathrm{~K} 5$ & $\mathrm{BPA}$ \\
\hline $\begin{array}{c}\text { Bobot } \\
(\mathrm{W})\end{array}$ & 0,292 & 0,237 & 0,226 & 0,154 & 0,090 & 1 \\
\hline & \multicolumn{7}{c}{$\begin{array}{c}\text { Alternatif } \\
\left(\mathrm{P}_{\mathrm{A}}\right)\end{array}$} & 0,495 & 0,420 & 0,420 & 0,420 & 0,420 & 0,441 \\
$\left(\mathrm{P}_{\mathrm{B}}\right)$ & 0,310 & 0,305 & 0,310 & 0,329 & 0,251 & 0,306 \\
$\left(\mathrm{P}_{\mathrm{C}}\right)$ & 0,196 & 0,275 & 0,270 & 0,251 & 0,329 & 0,252 \\
\hline
\end{tabular}

Nilai BPA tertinggi untuk bobot prioritas subkriteria kualitas terdapat pada pada pada pemasok $P_{A}$ sebesar 0,441 yang artinya pemasok tersebut memiliki tingkat kepentingan tertinggi terhadap kualitas kayu yang akan dipasok untuk perusahaan raket "ABADI"malang. 
Taabel 14. Bobot prioritas subkriteria "Harga"

\begin{tabular}{ccccc}
\hline $\begin{array}{c}\text { Subkriteria } \\
\text { Harga }\end{array}$ & $\mathrm{H} 1$ & $\mathrm{H} 2$ & $\mathrm{H} 3$ & $\mathrm{BPA}$ \\
\hline $\begin{array}{c}\text { Bobot } \\
(\mathrm{W})\end{array}$ & 0,392 & 0,357 & 0,251 & 1 \\
\hline & & Alteratif & \\
\hline$\left(\mathrm{P}_{\mathrm{A}}\right)$ & 0,390 & 0,367 & 0,407 & 0,386 \\
$\left(\mathrm{P}_{\mathrm{B}}\right)$ & 0,356 & 0,331 & 0,337 & 0,342 \\
$\left(\mathrm{P}_{\mathrm{C}}\right)$ & 0,254 & 0,302 & 0,256 & 0,272 \\
\hline
\end{tabular}

Nilai BPA tertinggi untuk bobot prioritas subkriteria harga terdapat pada pada pada pemasok $P_{A}$ sebesar 0,386 yang artinya pemasok tersebut memiliki tingkat kepentingan tertinggi terhadap harga kayu yang akan dipasok untuk perusahaan raket "ABADI"malang.

Tabel 15. Bobot Prioritas Subkriteria "Servis"

\begin{tabular}{ccccc}
\hline $\begin{array}{c}\text { Subkriteria } \\
\text { Servis }\end{array}$ & $\mathrm{S} 1$ & $\mathrm{~S} 2$ & $\mathrm{~S} 3$ & $\mathrm{BPA}$ \\
\hline $\begin{array}{c}\text { Bobot } \\
(\mathrm{W})\end{array}$ & 0,376 & 0,259 & 0,365 & 1 \\
\hline & & Alternatif & \\
\hline$\left(\mathrm{P}_{\mathrm{A}}\right)$ & 0,392 & 0,385 & 0,390 & 0,389 \\
$\left(\mathrm{P}_{\mathrm{B}}\right)$ & 0,357 & 0,354 & 0,344 & 0,352 \\
$\left(\mathrm{P}_{\mathrm{C}}\right)$ & 0,251 & 0,261 & 0,266 & 0,259 \\
\hline
\end{tabular}

Nilai BPA tertinggi untuk bobot prioritas subkriteria servis terdapat pada pada pada pemasok $P_{A}$ sebesar 0,389 yang artinya pemasok tersebut memiliki tingkat kepentingan tertinggi terhadap servis yang akan diberikan untuk perusahaan raket "ABADI"malang.

Tabel 16. Bobot prioritas subkriteria "Pengiriman"

\begin{tabular}{ccccc}
\hline $\begin{array}{c}\text { Subkriteria } \\
\text { Pengiriman }\end{array}$ & $\mathrm{P} 1$ & $\mathrm{P} 2$ & $\mathrm{P} 3$ & $\mathrm{BPA}$ \\
\hline $\begin{array}{c}\text { Bobot } \\
(\mathrm{W})\end{array}$ & 0,432 & 0,313 & 0,255 & 1 \\
\hline & & Alternatif & \\
\hline$\left(\mathrm{P}_{\mathrm{A}}\right)$ & 0,357 & 0,424 & 0,420 & 0,394 \\
$\left(\mathrm{P}_{\mathrm{B}}\right)$ & 0,381 & 0,358 & 0,329 & 0,361 \\
$\left(\mathrm{P}_{\mathrm{C}}\right)$ & 0,261 & 0,219 & 0,251 & 0,245 \\
\hline
\end{tabular}

Nilai BPA tertinggi untuk bobot prioritas subkriteria pengiriman terdapat pada pada pada pemasok $P_{A}$ sebesar 0,400 yang artinya pemasok tersebut memiliki tingkat kepentingan tertinggi terhadap harga kayu yang akan dipasok untuk perusahaan raket "ABADI"malang.

Tabel 17. Bobot prioritas subkriteria "Fleksibel"

\begin{tabular}{ccccc}
\hline $\begin{array}{c}\text { Subkriteria } \\
\text { Fleksibel }\end{array}$ & $\mathrm{F} 1$ & $\mathrm{~F} 2$ & $\mathrm{~F} 3$ & $\mathrm{BPA}$ \\
\hline $\begin{array}{c}\text { Bobot } \\
(\mathrm{W})\end{array}$ & 0,385 & 0,261 & 0,354 & 1 \\
\hline & & Alternatif & \\
\hline$\left(\mathrm{P}_{\mathrm{A}}\right)$ & 0,256 & 0,266 & 0,398 & 0,309 \\
$\left(\mathrm{P}_{\mathrm{B}}\right)$ & 0,407 & 0,390 & 0,331 & 0,376 \\
$\left(\mathrm{P}_{\mathrm{C}}\right)$ & 0,337 & 0,344 & 0,271 & 0,315 \\
\hline
\end{tabular}


Nilai BPA tertinggi untuk bobot prioritas subkriteria fleksibel terdapat pada pada pada pemasok $P_{B}$ sebesar 0,375 yang artinya pemasok tersebut memiliki tingkat kepentingan tertinggi terhadap fleksibel dalam proses pemesanan bahan baku yang akan dipasok untuk perusahaan raket "ABADI"malang.

Tabel 18. Bobot prioritas subkriteria "Sistem Komonikasi"

\begin{tabular}{ccccc}
\hline $\begin{array}{c}\text { Subkriteria } \\
\text { Sistem } \\
\text { Komunikasi }\end{array}$ & Sk1 & Sk2 & Sk3 & BPA \\
\hline $\begin{array}{c}\text { Bobot } \\
(\mathrm{W})\end{array}$ & 0,389 & 0,233 & 0,378 & 1 \\
\hline & & Alternatif & \\
\hline$\left(\mathrm{P}_{\mathrm{A}}\right)$ & 0,381 & 0,420 & 0,344 & 0,376 \\
$\left(\mathrm{P}_{\mathrm{B}}\right)$ & 0,381 & 0,305 & 0,387 & 0,366 \\
$\left(\mathrm{P}_{\mathrm{C}}\right)$ & 0,237 & 0,275 & 0,269 & 0,258 \\
\hline
\end{tabular}

Nilai BPA tertinggi untuk bobot prioritas subkriteria sistem komonikasi terdapat pada pada pada pemasok $P_{A}$ sebesar 0,376 yang artinya pemasok tersebut memiliki tingkat kepentingan tertinggi terhadap fleksibel dalam proses pemesanan bahan baku yang akan dipasok untuk perusahaan raket "ABADI"malang.

\subsection{Perangkingan bobot global}

Dari masing-masing kesimpulan tabel bobot prioritas alternatif terhadap subkriteria diatas, maka diperoleh nilai bobot global yang paling optimum, Berikut ini merupakan tabel hasil keputusan perangkingan nilai bobot prioritas.

Tabel 19. Perangkingan "Bobot Global"

\begin{tabular}{|c|c|c|c|c|c|c|c|c|}
\hline & $\begin{array}{l}\text { Kualitas } \\
\text { (K) }\end{array}$ & $\begin{array}{l}\text { Harga } \\
(\mathrm{H})\end{array}$ & $\begin{array}{l}\text { Servis } \\
\text { (S) }\end{array}$ & $\begin{array}{l}\text { Pengiriman } \\
\text { (P) }\end{array}$ & $\begin{array}{l}\text { Fleksibel } \\
\text { (F) }\end{array}$ & $\begin{array}{l}\text { Sistem } \\
\text { Komonikasi } \\
\text { (Sk) }\end{array}$ & $\begin{array}{l}\text { Bobot } \\
\text { Global }\end{array}$ & Rangking \\
\hline $\begin{array}{l}\text { Bobot } \\
\text { (W) }\end{array}$ & 0,222 & 0,233 & 0,192 & 0,142 & 0,140 & 0,071 & & \\
\hline & \multicolumn{8}{|c|}{ Alternatif } \\
\hline$\left(\mathrm{P}_{\mathrm{A}}\right)$ & 0,441 & 0,386 & 0,389 & 0,394 & 0,309 & 0,376 & 0,389 & 1 \\
\hline$\left(\mathrm{P}_{\mathrm{B}}\right)$ & 0,306 & 0,342 & 0,352 & 0,361 & 0,376 & 0,366 & 0,345 & 2 \\
\hline$\left(\mathrm{P}_{\mathrm{C}}\right)$ & 0,252 & 0,272 & 0,259 & 0,245 & 0,315 & 0,258 & 0,266 & 3 \\
\hline
\end{tabular}

Dapat disimpulkan bahwa alternatif pemasok A memiliki nilai yang paling optimum di bandingkan dengan pemasok $\mathrm{B}$ dan pemasok $C$. Oleh karena itu, Pemasok $P_{A}$ dapat disimpulkan sebagai pemasok terbaik. Namun, hasil keputusan ini hanya sebagai rekomendasi untuk perusahaan dalam mengambil keputusan.

\section{Simpulan}

Berdasarkan penelitian yang telah dilakukan dengan menggunakan metode Fuzzy AHP maka dapat diambil suatu kesimpulan sebagai berikut : Hasil dari perhitungan pemasok terbaik adalah pemasok (A) dengan rangking 1 yaitu dengan nilai bobot global sebesar 0,389 . 


\section{Referensi}

[1] E. Sonalitha, M. Sarosa, and A. Naba, "Pemilihan Pemasok Bahan Mentah pada Restoran Menggunakan Metode Fuzzy Analytical Hierarchy Process," Jurnal EECCIS, vol. 9, pp. 49-54, 2015.

[2] Y. Razandi, H. R. Pourghasemi, N. S. Neisani, and O. Rahmati, "Application of analytical hierarchy process, frequency ratio, and certainty factor models for groundwater potential mapping using GIS," Earth Science Informatics, vol. 8, pp. 867-883, 2015.

[3] Y. ChangD, "Application of the extent analysis method on fuzzy A HP," European Journal of Operational Research, vol. 95, pp. 649-655, 1996.

[4] K. Mathiyazhagan, A. Diabat, A. Al-Refaie, and L. Xu, "Application of analytical hierarchy process to evaluate pressures to implement green supply chain management," Journal of Cleaner Production, vol. 107, pp. 229-236, 2015.

[5] C. Sundarabalan, K. Selvi, and K. S. Kubra, "Performance investigation of fuzzy logic controlled MPPT for energy efficient solar PV systems," in Power Electronics and Renewable Energy Systems, ed: Springer, 2015, pp. 761-770.

[6] L. Suganthi, S. Iniyan, and A. A. Samuel, "Applications of fuzzy logic in renewable energy systems-a review," Renewable and Sustainable Energy Reviews, vol. 48, pp. 585-607, 2015.

[7] Y. Anshori, "Pendekatan Triangular Fuzzy Number dalam Metode Analytic Hierarchy Process," FORISTEK, vol. 2, 2012.

[8] T. Saaty, "Proses Hirarki Analitik untuk Pengambilan Keputusan dalam Situasi yang Kompleks (Terjemahan)," ed: PT Pustaka Binaman Pressindo, Jakarta, 1991.

[9] N. Kazakis, I. Kougias, and T. Patsialis, "Assessment of flood hazard areas at a regional scale using an index-based approach and Analytical Hierarchy Process: Application in Rhodope-Evros region, Greece," Science of the Total Environment, vol. 538 , pp. 555-563, 2015.

[10] H. Deng, "Multicriteria analysis with fuzzy pairwise comparison," in Fuzzy Systems Conference Proceedings, 1999. FUZZ-IEEE'99. 1999 IEEE International, 1999, pp. 726-731. 